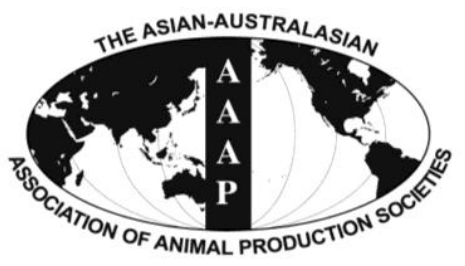

Asian-Aust. J. Anim. Sci.

Vol. 26, No. 1 : 59-64 January 2013

http://dx.doi.org/10.5713/ajas.2012.12355

www.ajas.info

pISSN 1011-2367 elSSN 1976-5517

\title{
Mineral Status in Cattle Fed Rice Straw and Para Grass Combined with Different Levels of Protein Derived from Cassava Foliage
}

\author{
K. Sath ${ }^{1,2}$, T. Pauly ${ }^{2}$ and K. Holtenius ${ }^{2, *}$ \\ ${ }^{1}$ Centre for Livestock and Agriculture Development (CelAgrid), P.O. Box 2423, Phnom Penh, Cambodia
}

\begin{abstract}
Eight male cattle of the Local Yellow breed with an average live weight of $121 \mathrm{~kg}$ and an average age of 18 months were used to evaluate the effects of different levels of sun-dried cassava (Manihot esculenta) foliage supplementation on mineral metabolism in growing cattle fed rice straw and para grass as basal diet. Rice straw ad libitum and para grass (Brachiaria mutica) at 1\% DM of BW comprised the basal diet. The study was arranged as a $4 \times 4$ double Latin square design, with cassava foliage contributing 0 , $0.8,1.6$ or $2.4 \mathrm{~g} \mathrm{CP} / \mathrm{kg} \mathrm{BW}$. The cassava foliage intake was lower than the planned levels. DM consumption was significantly affected by cassava foliage supplementation, with the largest intake observed at the two highest levels of cassava foliage supplementation. Rice straw intake showed the opposite pattern, with lower intake at higher cassava foliage supplementation. No refusals occurred for para grass in any of the treatments. $\mathrm{Ca}, \mathrm{P}, \mathrm{Mg}, \mathrm{K}, \mathrm{S}$ and $\mathrm{Mn}$ intake increased significantly with increasing intake of cassava foliage, but $\mathrm{Na}$ intake was not affected by treatment. Faecal excretion of $\mathrm{Ca}, \mathrm{Mg}, \mathrm{S}$ and $\mathrm{Mn}$ increased significantly with increasing cassava foliage intake. There were no differences between $\mathrm{P}, \mathrm{K}$ and $\mathrm{Na}$ excretion in faeces. There was a significant diet effect on $\mathrm{Mg}, \mathrm{S}$ and $\mathrm{Mn}$ digestibility. $\mathrm{Mg}$ and $\mathrm{Mn}$ digestibility increased with increasing cassava foliage supplementation, while S digestibility decreased. Ca, $\mathrm{P}$, $\mathrm{K}$ and Na digestibility was not affected by diet. There was a significant effect of treatment on $\mathrm{P}$ retention, with the highest value observed for supplementation with $1.6 \mathrm{~g} \mathrm{CP} / \mathrm{kg} \mathrm{BW}$ cassava foliage. $\mathrm{Ca}$ and $\mathrm{Mg}$ showed similar trends, with the highest retention again for supplementation with $1.6 \mathrm{~g} \mathrm{CP} / \mathrm{kg} \mathrm{BW}$ cassava foliage. There were weak but significant positive correlations between nitrogen retention and the macro minerals $\mathrm{Ca}, \mathrm{P}$ and $\mathrm{Mg}$. Furthermore, retention of all these minerals was positively correlated. Mineral losses in urine were not affected by dietary treatment with the exception of $\mathrm{P}$ excretion, which was affected by treatment. In conclusion, cassava foliage is a good $\mathrm{Ca}$ source which compensates for the low Ca content in rice straw and para grass, but $\mathrm{P}$ deficiency appears to be exaggerated in cattle with higher cassava intake. The results suggest that under these conditions growing cattle on a high cassava intake would benefit from P and S supplementation. (Key Words: Digestibility, Intake, Retention, Cassava Foliage, Rice Straw, Para Grass)
\end{abstract}

\section{INTRODUCTION}

Tropical feed stuffs vary markedly in content of essential minerals and usually do not meet the requirement of growing cattle. Phosphorus $(\mathrm{P})$ deficient soils occur in Thailand, Cambodia and many other countries in the tropical regions, resulting in P-deficient crops (Smithson and Giller, 2002). Cattle consuming diets not meeting their $\mathrm{P}$ requirements exhibit reduced growth and feed efficiency and decreased dry matter (DM) intake, and develop weak and fragile bones (Suttle, 2010). Cattle production in

\footnotetext{
* Corresponding Author: K. Holtenius. Tel: +46(0)18671629, Fax: +46(0)18672946, E-mail: Kjell.Holtenius@slu.se

2 Department of Animal Nutrition and Management, Swedish University of Agricultural Sciences (SLU), Kungsängen Research Centre, SE 753 23, Uppsala, Sweden.

Submitted Jun. 25, 2012; Accepted Sept. 18, 2012; Revised Sept. 26, 2012
}

Cambodia and other countries in tropical areas of Asia is strongly associated with rice cultivation and the by-product rice straw is a commonly used feed source (Sath et al., 2008). The level of phosphorus in rice straw is less than the level that animals need for growth (Nath et al., 1969). The content of available $\mathrm{Ca}$ is also generally marginal in rice straw (Joshi and Talapatra, 1968). It has recently been shown that the performance of growing cattle fed rice straw and para grass improves when the diet is supplemented with cassava foliage (Sath et al., 2012). However, it is well established that cassava contains cyanogenic glucosides, which are potentially toxic for ruminants, but dietary organic sulphur may detoxify these glucosides (Promkot and Wanapat, 2009).

Information about the mineral balance of growing cattle in South East Asia consuming diets typical for the region appears to be scarce. Thus the aim of the present study was 
to study mineral metabolism in growing cattle fed rice straw, para grass and cassava foliage.

\section{MATERIALS AND METHODS}

\section{Location}

The experiment was carried out at the Centre for Livestock and Agriculture Development, about $25 \mathrm{~km}$ south of Phnom Penh, Cambodia. The daily temperature during the experiment ranged from 26 to $32^{\circ} \mathrm{C}$. The experiment was conducted from May to July, 2009.

\section{Animal and experimental design}

The animals used comprised eight male cattle of the Local Yellow breed with an average body weight (BW) of $121 \mathrm{~kg}$ (18 months of the age) at the start of the experiment. The cattle were wormed using ivermectin and vaccinated against foot-and-mouth disease prior to the experiment. They were kept in individual metabolic cages $(1 \mathrm{~m} \times 1.8 \mathrm{~m}$, with roof) allowing total collection of urine and faeces and had free access to the experimental diets. The experimental setup was a $4 \times 4$ double Latin square design with periods of $15 \mathrm{~d}$ on each treatment, $10 \mathrm{~d}$ for adaptation and $5 \mathrm{~d}$ for data collection.

The four diets were:

$\mathrm{T}_{1}$ : Rice straw+para grass

$\mathrm{T}_{2}$ : Rice straw+para grass+sun-dried cassava foliage $(0.8 \mathrm{~g} \mathrm{CP} / \mathrm{kg} \mathrm{BW})$

$\mathrm{T}_{3}$ : Rice straw+para grass+sun-dried cassava foliage (1.6 g CP/kg BW)

$\mathrm{T}_{4}$ : Rice straw+para grass+sun-dried cassava foliage (2.4 g CP/kg BW)

\section{Diet and feeding}

The cattle were fed rice straw ad libitum and para grass at $1 \% \mathrm{DM}$ of $\mathrm{BW}$ as the basal diet and only the level of cassava foliage differed between the four experimental diets. Rice straw was collected after harvesting of rice grown during the rainy season and stored under cover. Para grass was grown as a monoculture, collected and stored for one day prior to feeding. Cassava foliage was collected at root harvesting. The cassava leaves plus petioles were separated from the hard stems and sun-dried for 3 to $5 \mathrm{~d}$ by spreading them on a plastic sheet placed on the ground. After sun drying, the foliage was stored under cover in hay bags. Para grass and rice straw were cut to about 30 to $40 \mathrm{~cm}$ length before feeding. Water was made available during the whole period. The experimental diets were fed three times a day, at 08:00, 12:00 and 16:00, in equal portions. The composition of the feeds is shown in Table 1. At the beginning and end of each period during the trial, the cattle were weighed in the morning before feeding.
Table 1. Chemical composition of feeds used in the experiment

\begin{tabular}{lcccc}
\hline & Rice straw & Para grass & $\begin{array}{c}\text { Cassava } \\
\text { leaves }\end{array}$ & $\begin{array}{c}\text { Cassava } \\
\text { petioles }\end{array}$ \\
\hline $\mathrm{DM}(\mathrm{g} / \mathrm{kg})$ & 895 & 194 & 879 & 886 \\
$\mathrm{In} \mathrm{g/kg} \mathrm{DM}$ & & & & \\
$\mathrm{CP}$ & 35 & 146 & 232 & 88 \\
$\mathrm{OM}$ & 866 & 879 & 923 & 917 \\
$\mathrm{Ca}$ & 3.1 & 2.8 & 13.6 & 20.5 \\
$\mathrm{P}$ & 0.5 & 2.5 & 1.8 & 0.7 \\
$\mathrm{Mg}$ & 0.7 & 2.4 & 3.5 & 3.6 \\
$\mathrm{~K}$ & 13.4 & 24 & 11.3 & 11.2 \\
$\mathrm{Na}$ & 0.8 & 8.3 & 0.05 & 0.1 \\
$\mathrm{~S}$ & 0.6 & 3.2 & 1.9 & 0.7 \\
$\mathrm{Mn}$ & 0.4 & 0.09 & 0.3 & 0.7 \\
\hline $\mathrm{D}$ & & & & \\
\hline
\end{tabular}

$\mathrm{DM}=$ Dry matter, $\mathrm{CP}=$ Crude protein, $\mathrm{OM}=$ Organic matter, $\mathrm{Ca}=$ Calcium, $\mathrm{P}=$ Phosphorus, $\mathrm{Mg}=$ Magnesium, $\mathrm{K}=$ Potassium, $\mathrm{Na}=$ Sodium, $\mathrm{S}=$ Sulphur, $\mathrm{Mn}=$ Manganese.

\section{Sample collection and analyses}

Feed refusals were collected and their DM weight recorded each morning for individual animals. Total collection of faeces and urine was performed on a daily basis during the last $5 \mathrm{~d}$ of the collection period. Subsamples of faeces were taken from daily samples and stored in a freezer. Approximately $1 \%$ of total urine excreted was sampled and stored in a freezer for subsequent analysis. The samples from each animal were pooled for each period before analysis.

The DM of feed and faecal samples was determined as described by Undersander et al. (1993). Crude protein CP $(\mathrm{N} \times 6.25)$ and ash were determined according to AOAC (1990). Ca, P, Mg, K, Na, S and Mn concentrations in feeds and faeces were determined by inductively coupled plasma optical emission spectroscopy (Spectroflame, Spectro Analytical Instruments $\mathrm{GmbH}$, Kleve, Germany) using $\mathrm{HNO}_{3}$ for extraction according to Balsberg-Påhlsson (1990). $\mathrm{Ca}, \mathrm{P}, \mathrm{Mg}, \mathrm{K}, \mathrm{Na}$ and $\mathrm{S}$ concentrations in urine were analysed by the same method.

\section{Statistical analysis}

The data were subjected to analysis of variance (ANOVA) using the General Linear Model procedure of MINITAB Software, version 16.1.1 (Minitab, 2010). Treatment means that showed significant differences at probability level $\mathrm{p}<0.05$ were compared using the Turkey's pair-wise comparison procedure. The following statistical model was used:

$$
\mathrm{y}_{\mathrm{ijk} k}=\mu+\mathrm{T}_{\mathrm{k}}+\mathrm{P}_{\mathrm{i}}+\mathrm{A}_{\mathrm{j}}+\mathrm{S}_{\mathrm{l}}+\mathrm{e}_{\mathrm{ijkl}}
$$

where $\mathrm{y}_{\mathrm{ijkl}}=$ the dependent variable, $\mu=$ overall mean value, $T_{k}=$ effect of treatment, $P_{i}=$ effect of period, $A_{j}=$ effect of animal, $\mathrm{S}_{1}=$ effect of square and $\mathrm{e}_{\mathrm{ijkl}}=$ effect of 
Table 2. Mean values of feed and nutrient intake and daily weight gain of cattle fed different diets

\begin{tabular}{lcccccr}
\hline & $\mathrm{T}_{1}$ & $\mathrm{~T}_{2}$ & $\mathrm{~T}_{3}$ & $\mathrm{~T}_{4}$ & $\mathrm{SEM}$ & $\mathrm{p}$ \\
\hline Feed intake (g DM/d) & & & & & & \\
$\quad$ Para grass & 1,293 & 1,304 & 1,280 & 1,253 & 20.6 & 0.350 \\
Rice straw & $2,173^{\mathrm{a}}$ & $1,962^{\mathrm{ab}}$ & $1,971^{\mathrm{ab}}$ & $1,824^{\mathrm{b}}$ & 69.9 & 0.017 \\
Cassava foliage & $0^{\mathrm{d}}$ & $460^{\mathrm{c}}$ & $875^{\mathrm{b}}$ & $1,149^{\mathrm{a}}$ & 28.7 & $<0.001$ \\
Total DMI & $3,466^{\mathrm{b}}$ & $3,727^{\mathrm{b}}$ & $4,125^{\mathrm{a}}$ & $4,225^{\mathrm{a}}$ & 72.4 & $<0.001$ \\
CPI (g/d) & $266^{\mathrm{d}}$ & $345^{\mathrm{c}}$ & $422^{\mathrm{b}}$ & $467^{\mathrm{a}}$ & 6.9 & $<0.001$ \\
OMI (g/d) & $3,019^{\mathrm{c}}$ & $3,269^{\mathrm{b}}$ & $3,636^{\mathrm{a}}$ & $3,738^{\mathrm{a}}$ & 62.9 & $<0.001$ \\
Total DM (\% BW) & $2.7^{\mathrm{b}}$ & $2.8^{\mathrm{b}}$ & $3.1^{\mathrm{a}}$ & $3.2^{\mathrm{a}}$ & 0.04 & $<0.001$ \\
Daily gain (g/d) & $155^{\mathrm{b}}$ & $251^{\mathrm{b}}$ & $469^{\mathrm{a}}$ & $492^{\mathrm{a}}$ & 52.2 & $<0.001$ \\
\hline
\end{tabular}

$\overline{\mathrm{a}, \mathrm{b}, \mathrm{c}}$ Means within rows with different subscript letters are significantly different $(\mathrm{p}<0.05)$

$\mathrm{DMI}=$ Dry matter intake, $\mathrm{CPI}=$ Crude protein intake, $\mathrm{OMI}=$ Organic matter intake .

random error.

On an individual basis, partial correlations were estimated among the variables $\mathrm{Ca}, \mathrm{P}, \mathrm{Mg}$ and $\mathrm{N}$ retention using the basic statistics option correlation in MINITAB Software, version 16.1.1 (Minitab, 2010).

\section{RESULTS}

\section{Feeds and mineral intake}

The actual intake of the different dietary components is shown in Table 2. The cassava foliage intake was lower than the planned levels of $0.8,1.6$ and $2.4 \mathrm{~g} \mathrm{CP} / \mathrm{kg} \mathrm{BW}$. Dry matter consumption was significantly affected by cassava foliage supplementation, with the largest intake observed at the two highest levels of cassava foliage supplementation (treatments $\mathrm{T}_{3}$ and $\mathrm{T}_{4}$ ). Rice straw intake showed the opposite pattern, with lower intake at higher cassava foliage supplementation. No refusals were seen for para grass, which was fed at $1 \% \mathrm{DM}$ of $\mathrm{BW}$ in all treatments. $\mathrm{Ca}, \mathrm{P}$, $\mathrm{Mg}, \mathrm{K}, \mathrm{S}$ and $\mathrm{Mn}$ intake increased significantly with increasing intake of cassava foliage, but $\mathrm{Na}$ intake was not affected by treatment (Table 3). The total intake of $\mathrm{P}$ and $\mathrm{S}$

Table 3. Mean mineral intake, excretion to faeces and digestibility in cattle fed the four diets

\begin{tabular}{|c|c|c|c|c|c|c|}
\hline & $\mathrm{T}_{1}$ & $\mathrm{~T}_{2}$ & $\mathrm{~T}_{3}$ & $\mathrm{~T}_{4}$ & SEM & $\mathrm{p}$ \\
\hline \multicolumn{7}{|c|}{ Intake (g/d) } \\
\hline $\mathrm{Ca}$ & $10.3^{\mathrm{d}}$ & $17^{\mathrm{c}}$ & $23.4^{\mathrm{b}}$ & $27^{\mathrm{a}}$ & 0.46 & $<0.001$ \\
\hline $\mathrm{P}$ & $4.4^{\mathrm{c}}$ & $5^{\mathrm{b}}$ & $5.6^{\mathrm{a}}$ & $5.8^{\mathrm{a}}$ & 0.09 & $<0.001$ \\
\hline $\mathrm{Mg}$ & $4.7^{\mathrm{d}}$ & $6.3^{c}$ & $7.8^{\mathrm{b}}$ & $8.7^{\mathrm{a}}$ & 0.13 & $<0.001$ \\
\hline K & $60^{c}$ & $62.8^{\mathrm{bc}}$ & $66.9^{\mathrm{ab}}$ & $67.4^{\mathrm{a}}$ & 1.11 & $<0.001$ \\
\hline $\mathrm{Na}$ & 12.3 & 12.3 & 12.2 & 11.9 & 0.20 & 0.304 \\
\hline S & $5.4^{\mathrm{c}}$ & $6^{\mathrm{b}}$ & $6.6^{\mathrm{a}}$ & $6.9^{\mathrm{a}}$ & 0.11 & $<0.001$ \\
\hline $\mathrm{Mn}$ & $1.1^{\mathrm{c}}$ & $1.2^{\mathrm{b}}$ & $1.3^{\mathrm{a}}$ & $1.4^{\mathrm{a}}$ & 0.03 & $<0.001$ \\
\hline \multicolumn{7}{|c|}{ Faeces $(\mathrm{g} / \mathrm{d})$} \\
\hline $\mathrm{Ca}$ & $7.4^{\mathrm{d}}$ & $11.7^{\mathrm{c}}$ & $15.3^{\mathrm{b}}$ & $20.3^{\mathrm{a}}$ & 0.70 & $<0.001$ \\
\hline $\mathrm{P}$ & 2.8 & 2.8 & 2.8 & 3.5 & 0.21 & 0.079 \\
\hline $\mathrm{Mg}$ & $3.5^{\mathrm{c}}$ & $4.2^{\mathrm{bc}}$ & $4.6^{\mathrm{b}}$ & $5.8^{\mathrm{a}}$ & 0.21 & $<0.001$ \\
\hline K & 7.1 & 8.1 & 7.8 & 9.4 & 0.74 & 0.207 \\
\hline $\mathrm{Na}$ & 2.4 & 1.8 & 1.8 & 1.8 & 0.26 & 0.271 \\
\hline S & $2^{c}$ & $2.5^{\mathrm{bc}}$ & $2.6^{\mathrm{b}}$ & $3.4^{\mathrm{a}}$ & 0.13 & $<0.001$ \\
\hline $\mathrm{Mn}$ & $0.9^{\mathrm{b}}$ & $0.9^{\mathrm{ab}}$ & $0.9^{\mathrm{ab}}$ & $1.1^{\mathrm{a}}$ & 0.04 & 0.013 \\
\hline \multicolumn{7}{|c|}{ Digestibility (g/kg intake) } \\
\hline $\mathrm{Ca}$ & 281 & 315 & 346 & 263 & 25.6 & 0.135 \\
\hline $\mathrm{P}$ & 362 & 427 & 502 & 414 & 37.9 & 0.104 \\
\hline $\mathrm{Mg}$ & $241^{\mathrm{b}}$ & $320^{\mathrm{ab}}$ & $408^{\mathrm{a}}$ & $344^{\mathrm{ab}}$ & 32.4 & 0.013 \\
\hline $\mathrm{K}$ & 883 & 871 & 885 & 863 & 9.8 & 0.367 \\
\hline $\mathrm{Na}$ & 807 & 852 & 853 & 851 & 21.4 & 0.365 \\
\hline$S$ & $623^{\mathrm{a}}$ & $587^{\mathrm{a}}$ & $606^{\mathrm{a}}$ & $519^{\mathrm{b}}$ & 16.4 & 0.001 \\
\hline $\mathrm{Mn}$ & $181^{\mathrm{b}}$ & $222^{\mathrm{ab}}$ & $313^{\mathrm{a}}$ & $236^{\mathrm{ab}}$ & 30.7 & 0.044 \\
\hline
\end{tabular}

\footnotetext{
$\overline{a, b, c}$ Means within rows with different subscript letters are significantly different $(\mathrm{p}<0.05)$.
} 
showed the same trend as the total intake of $\mathrm{Mn}$, i.e. significant differences between $T_{1}$ and $T_{2}$ and the two highest cassava levels $\left(\mathrm{T}_{3}+\mathrm{T}_{4}\right)$ but with no significant differences between $\mathrm{T}_{3}$ and $\mathrm{T}_{4}$. Ca and $\mathrm{Mg}$ intake showed the same significant trend among treatments (Table 3 ).

\section{Mineral digestibility and retention}

Faecal excretion of $\mathrm{Ca}, \mathrm{Mg}, \mathrm{S}$ and $\mathrm{Mn}$ increased significantly with increasing intake of cassava foliage intake. There were no differences between $\mathrm{P}, \mathrm{K}$ and $\mathrm{Na}$ excretion in faeces. Faecal excretion of $\mathrm{Mg}$ and $\mathrm{S}$ showed the same trend, i.e. significant differences between the group fed no cassava foliage $\left(\mathrm{T}_{1}\right)$ and the two groups with the highest cassava foliage intake $\left(\mathrm{T}_{3}+\mathrm{T}_{4}\right)$ but no difference between $T_{2}$ and $T_{3}$ diets. Mn faecal excretion only differed between the $\mathrm{T}_{1}$ and $\mathrm{T}_{4}$ diets (Table 3 ). However, there was a significant effect of diet on $\mathrm{Mg}, \mathrm{S}$ and $\mathrm{Mn}$ digestibility. $\mathrm{Mg}$ and $\mathrm{Mn}$ digestibility increased with increasing cassava foliage supplementation, while $\mathrm{S}$ digestibility decreased (Table 3). The highest digestibility of both $\mathrm{Mg}$ and $\mathrm{Mn}$ was observed for diet $T_{3}$ and the lowest for $\operatorname{diet} T_{1}$. The lowest $S$ digestibility was observed with diet $\mathrm{T}_{4}$, which was significantly lower than for the other three diets $\left(\mathrm{T}_{1}-\mathrm{T}_{3}\right)$. Ca, $\mathrm{P}, \mathrm{K}$ and Na digestibility was not affected by diet. There was a significant effect of treatment on $\mathrm{P}$ retention, with the highest value observed for treatment $\mathrm{T}_{3}$. Ca and $\mathrm{Mg}$ showed similar trends, with the highest retention also for treatment $\mathrm{T}_{3}$ (Table 4). There were weak but significant positive correlations between nitrogen retention and the macro minerals $\mathrm{Ca}, \mathrm{P}$ and $\mathrm{Mg}$. Furthermore, the retention values of all these minerals were positively correlated (Table 5). Mineral losses in urine were generally not affected by diet with the exception of $\mathrm{P}$ excretion, which was higher for treatment $\mathrm{T}_{4}$ than for $\mathrm{T}_{1}$ (Table 4 ).
Table 5. Correlations (r, p-value) between $\mathrm{N}, \mathrm{Ca}, \mathrm{P}$ and $\mathrm{Mg}$ retention

\begin{tabular}{llcc}
\hline & $\begin{array}{c}\text { N retention } \\
(\mathrm{g})\end{array}$ & $\begin{array}{c}\text { Ca retention } \\
(\mathrm{g})\end{array}$ & $\begin{array}{c}\text { P retention } \\
(\mathrm{g})\end{array}$ \\
\hline Ca retention $(\mathrm{g})$ & $0.516^{* * *}$ & - & - \\
P retention $(\mathrm{g})$ & $0.357^{*}$ & $0.870^{* * *}$ & - \\
Mg retention $(\mathrm{g})$ & $0.498^{* * *}$ & $0.859^{* * *}$ & $0.864 * * *$ \\
\hline$* \mathrm{p}<0.05, * * * \mathrm{p}<0.001$ & & &
\end{tabular}

\section{DISCUSSION}

\section{Ca and $P$ intake and metabolism}

A number of minerals are essential in the animal diet. In growing cattle, the maintenance and growth requirements of essential minerals must be covered by the diet provided. The concentration of minerals in different forages varies greatly. In the present study rice straw, para grass and varying amounts of sun-dried cassava foliage were offered to growing cattle in Cambodia. The different dietary combinations gave rise to significant variations in intake of all minerals studied except $\mathrm{Na}$. As expected, the concentration of $\mathrm{Ca}$ in both rice straw and para grass was low. Thus cattle only consuming rice straw and para grass had a deficient intake of $\mathrm{Ca}$ based on current recommendations for growing cattle (Nielsen and Volden, 2011). On the other hand, the content of $\mathrm{Ca}$ in cassava leaves and petioles was high. This confirms results presented by Gomez and Valdivieso (1985) showing high levels of $\mathrm{Ca}$ in dried cassava foliage. Cassava proved to be a good $\mathrm{Ca}$ source and can be used in order to supplement feeds with a poor $\mathrm{Ca}$ content. However, the $\mathrm{P}$ content was rather low in cassava foliage. The $\mathrm{Ca} / \mathrm{P}$ ratio increased in treatments with higher cassava inclusion. In the diet with the highest cassava inclusion, the $\mathrm{Ca} / \mathrm{P}$ ratio was 4.7 , far above the generally accepted safe range of 1:1 to 2:1 (ARC,

Table 4. Mineral excretion to urine, retention and concentration in blood plasma of cattle fed the four diets

\begin{tabular}{|c|c|c|c|c|c|c|}
\hline & $\mathrm{T}_{1}$ & $\mathrm{~T}_{2}$ & $\mathrm{~T}_{3}$ & $\mathrm{~T}_{4}$ & SEM & $\mathrm{p}$ \\
\hline \multicolumn{7}{|c|}{ Urine (g/d) } \\
\hline $\mathrm{Ca}$ & 0.02 & 0.02 & 0.02 & 0.02 & 0.002 & 0.146 \\
\hline $\mathrm{P}$ & $0.01^{\mathrm{b}}$ & $0.01^{\mathrm{ab}}$ & $0.01^{\mathrm{ab}}$ & $0.02^{\mathrm{a}}$ & 0.001 & 0.028 \\
\hline $\mathrm{Mg}$ & 0.5 & 0.5 & 0.7 & 0.6 & 0.072 & 0.286 \\
\hline K & 34.5 & 36.9 & 36.9 & 39.8 & 2.19 & 0.414 \\
\hline $\mathrm{Na}$ & 5.3 & 5.8 & 5.1 & 5.8 & 0.43 & 0.582 \\
\hline S & 1.7 & 2.0 & 1.8 & 1.9 & 0.12 & 0.280 \\
\hline \multicolumn{7}{|c|}{ Retention (g/d) } \\
\hline $\mathrm{Ca}$ & $2.9^{\mathrm{c}}$ & $5.3^{\mathrm{b}}$ & $8.1^{\mathrm{a}}$ & $6.7^{\mathrm{ab}}$ & 0.59 & $<0.001$ \\
\hline $\mathrm{P}$ & $1.6^{\mathrm{b}}$ & $2.1^{\mathrm{ab}}$ & $2.8^{\mathrm{a}}$ & $2.4^{\mathrm{a}}$ & 0.18 & 0.002 \\
\hline $\mathrm{Mg}$ & $0.7^{\mathrm{c}}$ & $1.5^{\mathrm{b}}$ & $2.5^{\mathrm{a}}$ & $2.3^{\mathrm{ab}}$ & 0.20 & $<0.001$ \\
\hline $\mathrm{Ca} / \mathrm{P}$ & 2.2 & 2.5 & 2.8 & 2.9 & 0.3 & 0.339 \\
\hline \multicolumn{7}{|c|}{ Blood plasma (mmol/L) } \\
\hline $\mathrm{Ca}$ & 1.8 & 1.8 & 1.8 & 1.9 & 0.05 & 0.737 \\
\hline $\mathrm{Mg}$ & 0.7 & 0.7 & 0.6 & 0.7 & 0.02 & 0.289 \\
\hline
\end{tabular}

\footnotetext{
${ }_{\mathrm{a}, \mathrm{b}, \mathrm{c}}$ Means within rows with different subscript letters are significantly different $(\mathrm{p}<0.05)$.
} 
1980). All diets were deficient in $\mathrm{P}$ in relation to the actual requirements of the animals (NRC, 2000; Nielsen and Volden, 2011). Growing calves of dairy breeds require 0.30 to $0.34 \% \mathrm{P}$ in the diet $\mathrm{DM}$, while the dietary $\mathrm{P}$ requirement of growing Zebu steers is even higher, (Silva de Almeida et al., 2009). In the present study the $\mathrm{P}$ content was about $0.13 \%$ of diet DM, i.e. markedly lower than recommended. While low urinary $\mathrm{P}$ excretion can be expected for ruminants, according to Puls (1994) a urine output below $3.6 \mathrm{mg} / \mathrm{L}$ indicates deficiency. In the present study the average urinary output was lower than this level in all dietary treatments, indicating that the cattle were P-deficient. Chizzotti et al. (2009) reported a significant linear relationship between retained $\mathrm{Ca}$ and retained $\mathrm{P}$ such that: $\mathrm{Ca}(\mathrm{g} / \mathrm{d})=2.57 \times$ retained $\mathrm{P}(\mathrm{g} / \mathrm{d})-0.44\left(\mathrm{r}^{2}=0.93\right)$. In the present study a corresponding, but weaker, relationship was observed: retained $\mathrm{Ca}(\mathrm{g} / \mathrm{d})=3.01 \times$ retained $\mathrm{P}(\mathrm{g} / \mathrm{d})-0.89\left(\mathrm{r}^{2}\right.$ $=0.76)$. This relationship indicates that less $\mathrm{P}$ was retained in relation to $\mathrm{Ca}$ than observed in the study by Chizzotti et al. (2009). Prolonged $\mathrm{P}$ deficiency results in clinical symptoms (Suttle, 2010). However, although the results clearly indicate that the cattle in the present study received too little dietary $\mathrm{P}$, there were no obvious effects on their performance.

\section{Mg and $S$ intake and metabolism}

The $\mathrm{Mg}$ content was relatively high in both cassava foliage and para grass, but low in rice straw, and $\mathrm{Mg}$ intake increased with increased cassava intake. However, even in cattle consuming no cassava, $\mathrm{Mg}$ intake was above the level recommended for cattle by NRC (2000). It is generally accepted that a surplus of absorbed $\mathrm{Mg}$ is rapidly excreted with the urine (Martens and Schweigel, 2000). The minimal inevitable loss of $\mathrm{Mg}$ with urine is 3 to $4 \mathrm{mg} / \mathrm{kg} \mathrm{BW}$ (Guéguen et al., 1989). The average BW of the cattle in the present study was $131 \mathrm{~kg}$ and the minimal Mg losses with urine would thus be about $0.5 \mathrm{~g} / \mathrm{d}$. The average $\mathrm{Mg}$ excretion did not fall below that level in any of the dietary treatments and there was no difference in daily urinary $\mathrm{Mg}$ excretion.

The required dietary content of $\mathrm{S}$ has been set to $1.5 \mathrm{~g}$ of the whole diet in growing cattle, which is normally assumed to satisfy the high requirements of rumen microbiota (NRC, 2000). In the present study the average intake was close to this level in all four treatments. However the $S$ requirement may increase in ruminants fed cassava and other feeds containing cyanogenic glucosides (Onwuka et al., 1992; Promkot and Wanapat, 2009). An increased level of S supplementation from 1.5 to $4 \mathrm{~g} / \mathrm{kg} \mathrm{DM}$ can be beneficial to cows consuming cassava foliage in terms of DM intake and it has been suggested that the increased $S$ intake facilitates cyanide detoxification (Promkot and Wanapat, 2009). In the present study the apparent S digestibility decreased significantly in cattle receiving the highest level of cassava supplementation. $S$ is mainly absorbed as S-containing amino acids in the small intestine (Doyle and Moir, 1980). Our results may reflect use of $\mathrm{S}$ for detoxification and thus reduced intestinal uptake of these amino acids. However, it also possible that the lower $\mathrm{S}$ digestibility reflected the overall reduced nutrient digestibility related to increased cassava consumption (Sath et al., 2012).

\section{$\mathrm{K}$ and $\mathrm{Na}$ intake and metabolism}

The $\mathrm{K}$ intake was mainly related to DM intake and was well above the requirement of growing cattle (Puls, 1994). More than $80 \%$ of the K consumed was excreted with urine, indicating that the capacity for absorption of $\mathrm{K}$ was high. There was a marked difference in $\mathrm{Na}$ content between the different feed sources. As expected, the Na content in both cassava foliage and rice straw was too low to satisfy the requirement of growing cattle (Fasuyiet, 2005). However, the $\mathrm{Na}$ content of para grass was higher and compensated for the low $\mathrm{Na}$ content in cassava and rice straw. The content of $\mathrm{Na}$ was efficiently absorbed and the surplus excreted with urine.

\section{$\mathrm{Ca}, \mathrm{P}, \mathrm{Mg}$ and $\mathrm{N}$ correlations}

Daily retention rates of $\mathrm{Ca}, \mathrm{P}$ and $\mathrm{Mg}$ were all strongly correlated with each other $(r=0.86-0.87)$. The correlations were expected, since the main fraction of these minerals is found in bone and their net retention presumably reflects bone mineralisation. However, it has been shown that the rate of bone mineralisation does not follow the rate of protein retention (Chizzoti et al., 2009). This lack of correlation is probably explained by the fact that soft tissues, which are the main pool of protein, contain only small amounts of Ca and P. Chizzoti et al. (2009) also suggested that the requirement for mineralisation diminishes relative to the requirement for protein as cattle grow heavier. In the present study, protein retention showed a moderate correlation to $\mathrm{Ca}$ retention and $\mathrm{Mg}$ retention (0.52 and 0.50, respectively). On the other hand, the correlation between protein retention and $\mathrm{P}$ retention was poorer (0.36), although still significant. It is possible that the poorer correlation of $\mathrm{P}$ to protein retention reflected the observed inadequate dietary $\mathrm{P}$ supply regardless of treatment. However, the significant relationship between bone mineralisation and protein accretion in the present study suggests that the skeletal tissue was still growing.

\section{CONCLUSIONS}

From the findings of this study, it can be concluded that cassava foliage is a good $\mathrm{Ca}$ source which compensates for the low Ca content in rice straw and para grass. However all 
feeds used here had a low $\mathrm{P}$ content and thus none of the diets provided enough $\mathrm{P}$ for the animals. The $\mathrm{P}$ deficiency appeared to be exaggerated in cattle with higher cassava intake. The results suggest that growing cattle, especially those on a high cassava intake, would benefit from supplementation with $\mathrm{P}$ and $\mathrm{S}$ under these conditions.

\section{ACKNOWLEDGEMENTS}

The authors are grateful to the Swedish International Development Agency for Research Cooperation with Developing Countries (Sida/SAREC), through the regional programme Mekong basin Agriculture Research Network (MEKARN), for financial support for this research.

\section{REFERENCES}

AOAC. 1990. Official method of analysis. $15^{\text {th }}$ edn, Association of Official Analytical Chemists. edition (Ed. K. Helrick). Arlington pp. 1230.

ARC. 1980. Agricultural research council. The Nutrient Requirements of Ruminant Livestock. Technical Review. Commonwealth Agricultural Bureaux, Farnham Royal.

Balsberg-Påhlsson, A. M. 1990. Förbehandling, uppslutning och extraktberedning av växt-och förnaprov. In: Handledning i Kemiska Metoder vid Växtekologiska Arbeten. Meddelanden från Växtekologiska Avdelningen, Lunds Universitet, Lund, Sweden, pp. 18-19.

Chizzotti, M. L., S. C. V. Filho, L. O. Tedeschi, P. V. R. Paulino, M. F. Paulino, R. F. D. Valadares, P. Amaral, P. D. B. Benedeti, T. I. Rodrigues and M. A. Fonseca. 2009. Net requirements of calcium, magnesium, sodium, phosphorus, and potassium for growth of Nellore $\times$ Red Angus bulls, steers and heifers. Livest. Sci. 124:242-247.

Doyle, P. T. and R. J. Moir. 1980. Sulfur and methionine metabolism in sheep. IV. Metabolism and absorption in the intestines. Aust. J. Biol. Sci. 33:303-307.

Fasuyiet, A. O. 2005. Nutrient composition and processing effects on cassava leaf (Manihot esculenta, Crantz) anti-nutrients. Pakistan J. Nutr. 4:37-42.

Gomez, G. and M. Valdivieso. 1985. Foliage and root production of field-grown cassava cultivars as affected by plant age. Turrialba 35:5-10.

Guéguen, L., M. Lamand and F. Meschy. 1989. Mineral requirements. In: Ruminant nutrition. Recommendation, allowances \& feed tables (Ed. R. Jarridge). INRA, John Libbey Eurotext, London-Paris, p. 52.
Joshi, D. C. and S. K. Talapatra. 1968. Studies on the utilization of minerals under acid- and alkali-producing cattle feeds. Indian J. Vet. Sci. Anim. Husb. 38:645-664.

Martens, H. and M. Schweigel. 2000. Pathophysiology of grass tetany and other hypomagnesemias; implication for clinical management. Vet. Clin. North Am. Food Anim. Pract. 16:339368.

Minitab. 2010. Minitab Statistical Software, Release 16.1.1 for Windows. (Minitab Inc. State College PA, USA).

Nath, K., K. Sahai and N. D. Kehar. 1969. Effect of water washing, lime treatment and lime and calcium carbonate supplementation on the nutritive value of paddy (Oryza sativa) straw. J. Anim. Sci. 28:383-385.

Nielsen, N. I. and H. Volden. 2011. In: NorFor - The Nordic feed evaluation system p. 85-112 (Ed. H. Volden). EAAP publication No. 130. Wageningen Academic Publishers. The Netherlands.

NRC. 2000. National research council, Nutrient Requirements of Beef Cattle, updated 7th ed. National Academy Press, Washington, USA.

Onwuka, C. F. I., A. O. Akinsoyinu and O. O. Tewe. 1992. Role of sulphur in cyanide detoxification in ruminants. Small Rumin. Res. 8:277-284.

Promkot, C. and M. Wanapat. 2009. Effect of elemental sulfur supplementation on rumen environment parameters and utilization efficiency of fresh cassava foliage and cassava hay in dairy cattle. Asian-Aust. J. Anim. Sci. 22:1366-1376.

Puls, R. 1994. Mineral levels in animal health: diagnostic data. Sherpa International, Clearbrook. pp 219 and 256.

Sath, K., K. Borin and T. R Preston. 2008. Effect of levels of sundried cassava foliage on growth performance of cattle fed rice straw. Livest. Res. Rural. Dev. 20 (Suppl.):1-12.

Sath, K., K. Sokun, T. Pauly and K. Holtenius. 2012. Feed intake, digestibility, and $\mathrm{N}$ retention in cattle fed rice straw and para grass combined with different levels of protein derived from cassava foliage. Asian-Aust. J. Anim. Sci. 25:956-961.

Silva de Almeida, V. V., A. C. Queiroz, R. R. Silva, F. F. da Silva, A. C. Oliviera and H. A. Jr. Santana. 2009. Body composition and net and dietary macrominerals requirements of Nellore steers under grazing. Revista Brasileira de Zootecnia 38:10811087.

Smithson, P. and K. Giller. 2002. Appropriate farm management practices for alleviating $\mathrm{N}$ and $\mathrm{P}$ deficiencies in low-nutrient soils of the tropics. Plant Soil 245:169-180.

Suttle, N. F. 2010. Mineral nutrition of livestock. CABI Wallington, pp. 122-167.

Undersander, D., D. R. Mertens and N. Theix. 1993. Forage analysis procedures. National Forage Testing Association. Omaha, p. 154. 